\title{
CCNB3 Gene
}

National Cancer Institute

\section{Source}

National Cancer Institute. CCNB3 Gene. NCI Thesaurus. Code C139671.

This gene plays a role in the regulation of mitosis and meiosis. 